Centre for Health in Employment and the Environment, Department of Occupational Health and Safety, United Bristol Healthcare Trust, Whitefriars Centre, Lewins Mead, Bristol BS1 2NT, UK Anthony Hughes Robin Philipp Kit Harling

Correspondence to: Dr Anthony Hughes, Centre for Health in Employment and the Environment, Department of Occupational Health and Safety, United Bristol Healthcare Trust, Whitefriars Centre, Lewins Mead, Bristol BS1 2NT, UK email Anthony.Hughes@ ubht.swest.nhs.uk

Accepted 17 May 1999

\title{
Provision and staffing of NHS occupational health services in England and Wales
}

\author{
Anthony Hughes, Robin Philipp, Kit Harling
}

\begin{abstract}
Objectives-To establish the extent of Occupational Health $(\mathrm{OH})$ service provision in the National Health Service (NHS).

Methods-Two postal questionnaires were used to obtain information from purchasers and providers in the NHS in England and Wales.

Results-99.6\% of trust and health authority employers claim to provide some form of $\mathrm{OH}$ service to their employees indicating widespread recognition of need, but virtually no service is provided to other staff such as general practitioners (GPs), general dental practitioners (GDPs), and their staff. There is a wide variability in the range and quality of $\mathrm{OH}$ services, suggested by the enormous differences in medical staffing levels, and the contractual restrictions where the $\mathrm{OH}$ service is provided by another NHS employer. Only about a third (highest estimate) to a quarter (lowest estimate) of NHS staff have access to a specialist occupational physician.

Conclusions-Substantial inequality of access to $\mathrm{OH}$ services exists for the NHS workforce, despite previous guidance. There is no real evidence to suggest why the extent of provision of $\mathrm{OH}$ services varies so greatly between institutions.

(Occup Environ Med 1999;56:714-717)
\end{abstract}

Keywords: NHS; staff; occupational health

The basic principle of the National Health Service (NHS) is that "comprehensive, high quality medical care should be available to all citizens on the basis of professionally judged medical need without financial barriers to access". ${ }^{1}$ However, there are ongoing concerns about the wellbeing of NHS staff ${ }^{2}$ and the clinical problems caused by work. ${ }^{3}$ Furthermore, it has been suggested recently that the health of NHS staff is poor when compared with other working populations. ${ }^{4}$

The Department of Health (DoH) has stated that "a healthy workforce is essential for the NHS to provide high-quality health care and to improve the health of the population"'. It considered that $\mathrm{OH}$ services should "have inde- pendent professional status and report to senior management". ${ }^{3}$ The British Medical Association, at the annual representatives' meeting, and the Nuffield Trust have also called for the provision of a comprehensive occupational health $(\mathrm{OH})$ service for NHS staff. $^{45}$

Recent guidance from the NHS Executive (NHSE) has again emphasised the need for all staff to have access to specialist consultant led $\mathrm{OH}$ services. ${ }^{6}$ This study was undertaken in early 1998 for the NHSE to determine the then current level of provision of $\mathrm{OH}$ services in the NHS in England and Wales.

\section{Method}

Initially a purchaser questionnaire was sent to all directors of personnel or human resources of the 618 NHS organisations identified from the electronic listing of Binley's directory. ${ }^{7}$ These 618 organisations comprised 455 NHS trusts, 105 health authorities and 58 other NHS sites. The questionnaire sought information about the role and size of the organisation, the number of employees and, if an $\mathrm{OH}$ service was provided for staff, whether the service was in house, provided by another NHS trust, or purchased from the private sector. Health authorities were asked whether they provided $\mathrm{OH}$ services to local general practitioners (GPs).

The replies to the purchaser questionnaire allowed identification of 259 NHS OH departments. These could be either a department run by the responding organisation, or a department run by some other organisation from whom $\mathrm{OH}$ services were purchased. The $\mathrm{OH}$ departments were mainly accommodated within NHS trusts. A provider questionnaire was sent to these departments seeking details of their clients, numbers, qualifications, and contracted hours of medical and nursing staff.

Reminders were not sent to any nonresponders, either purchasers or providers, as the NHSE could only allow 2 months for the study to be completed. The four purchaser and 10 provider questionnaires received after the original closing date have been incorporated in the results.

\section{Results}

The response rates to the initial questionnaire were $94 \%$ for NHS trusts, $86 \%$ for health 
Table 1 Medical manpower in occupational health departments

\begin{tabular}{|c|c|}
\hline & $n(\%)$ \\
\hline \multicolumn{2}{|l|}{ Doctors in the service: } \\
\hline Total doctors & 362 \\
\hline \multicolumn{2}{|l|}{ Grade of doctor: } \\
\hline Consultants & $96(27)$ \\
\hline Locum consultant & $26(7)$ \\
\hline Specialist registrars & $35(10)$ \\
\hline Clinical assistants & $112(31)$ \\
\hline Other hospital posts & $51(14)$ \\
\hline Non-NHS posts & $42(12)$ \\
\hline \multicolumn{2}{|l|}{ With qualifications: } \\
\hline FFOM & $55(15)$ \\
\hline MFOM & $66(18)$ \\
\hline AFOM & $67(19)$ \\
\hline Other $\mathrm{OH}$ & $54(15)$ \\
\hline No OH & $120(33)$ \\
\hline \multicolumn{2}{|l|}{ Working hours: } \\
\hline Full time & $51(14)$ \\
\hline Part time & $311(86)$ \\
\hline Total sessions/week & 1285.7 \\
\hline Average sessions/week & 3.55 \\
\hline \multicolumn{2}{|l|}{ Occupational health departments: } \\
\hline Total departments & 198 \\
\hline \multicolumn{2}{|l|}{ Doctors employed: } \\
\hline 1 & $107(54)$ \\
\hline 2 & $51(26)$ \\
\hline$\geqslant 3$ & $40(21)$ \\
\hline \multicolumn{2}{|l|}{ Highest qualified doctor: } \\
\hline$\geqslant 1$ Consultants & $87(44)$ \\
\hline FFOM/MFOM & $102(51)$ \\
\hline AFOM or Occ Dip & $61(31)$ \\
\hline Without $\mathrm{OH}$ qualification & $35(18)$ \\
\hline At least 1 full time doctor & $76(38)$ \\
\hline \multicolumn{2}{|l|}{ Sessions of doctor time/week: } \\
\hline$\leqslant 2$ & $76(38)$ \\
\hline $2-5$ & $52(26)$ \\
\hline $5-10$ & $29(15)$ \\
\hline$>10$ & $41(21)$ \\
\hline
\end{tabular}

authorities, and $53 \%$ for other NHS organisations giving an overall response rate of $89 \%$ (550/618). The 429 responding trusts employed 96\% (723000 whole time equivalents (WTEs)) of the workforce within this sector of the service. These trusts reported a total of 905000 employees, an inflation of $25 \%$ over WTE figures.

Thirty eight per cent of trusts provide the service in house, $57 \%$ purchase from some other trust, $4 \%$ purchase privately, and $0.4 \%$ make no provision. From these figures we estimate that about $70 \%$ of employees will have a service based with their employer, a further $27 \%$ from some other local trust, and about 3\% consult in the private sector. In the case of dispersed organisations - for example, NHS Supplies, National Blood Authority-provision was established either in house or with different trusts dependent on the locality of the workers.

The responses of the health authorities suggested that most (79 out of 90) have no formal arrangement to provide $\mathrm{OH}$ services to their GPs or their staff. Six authorities reported a full $\mathrm{OH}$ service for GPs, two had a partial service - a counselling service-and three failed to provide any information on GP services. A few health authorities indicated that this matter was presently under review and may be included in a future financial year.

One hundred and ninety eight $\mathrm{OH}$ departments returned details of their services, giving a response rate of $76 \%$ to the provider questionnaire. These departments provide services to $75 \%$ of the 618 NHS organisations. Seventy three per cent of organisations select to purchase a full $\mathrm{OH}$ provision, although the
Table 2 Nursing manpower in occupational health departments

\begin{tabular}{|c|c|}
\hline & $n(\%)$ \\
\hline \multicolumn{2}{|l|}{ Nurses in the service: } \\
\hline Total nurses & 735 \\
\hline \multicolumn{2}{|l|}{ Grade of nurse: } \\
\hline RGN & $711(97)$ \\
\hline $\mathrm{EN}$ & $22(3)$ \\
\hline Other basic qualification & $2(-)$ \\
\hline \multicolumn{2}{|l|}{ Specialist qualification: } \\
\hline OH degree & $64(9)$ \\
\hline OHND & $193(26)$ \\
\hline OHNC & $195(27)$ \\
\hline trainee for $\mathrm{OHNC} / \mathrm{D}$ & $108(15)$ \\
\hline No OH certificate & $175(24)$ \\
\hline \multicolumn{2}{|l|}{ Working hours: } \\
\hline Full time & $507(69)$ \\
\hline Part time & $228(31)$ \\
\hline Total hours/week & 22835.6 \\
\hline Average hours/week & 31 \\
\hline \multicolumn{2}{|c|}{ Occupational health departments: } \\
\hline Total departments & 198 \\
\hline \multicolumn{2}{|l|}{ Nurses employed } \\
\hline 1 & $29(15)$ \\
\hline 2 & $47(24)$ \\
\hline 3 & $37(19)$ \\
\hline 4 & $27(14)$ \\
\hline$\geqslant 5$ & $58(29)$ \\
\hline \multicolumn{2}{|l|}{ Highest qualified nurse: } \\
\hline $\mathrm{OH}$ degree/OHND & $136(69)$ \\
\hline OHNC/trainee & $57(29)$ \\
\hline No $\mathrm{OH}$ qualification & $5(2)$ \\
\hline At least 1 full time nurse & $189(96)$ \\
\hline \multicolumn{2}{|l|}{ Total nursing hours/week: } \\
\hline$<36$ & $9(4)$ \\
\hline $37-74$ & $60(33)$ \\
\hline $75-112$ & $46(23)$ \\
\hline $112.5-150$ & $25(13)$ \\
\hline$>150$ & $53(27)$ \\
\hline
\end{tabular}

remainder have specific service level (restricted) agreements.

The questionnaire established the medical staffing of these departments. Details are shown in table 1 . Although all departments had at least one medically qualified staff member, a full time doctor was appointed in only $38 \%$. In two thirds of departments there was medical cover for less than half the working week. There is the potential for full time medical cover in about one in five $\mathrm{OH}$ departments. Forty per cent of departments have an established consultant with appropriate specialist qualifications - membership or fellowship of the Faculty of Occupational Medicine (F/ MFOM). A further $12 \%$ of departments have a qualified MFOM but not in an established consultant post. In $18 \%$ of departments no doctor holds any recognised qualifications in occupational medicine.

The qualifications and time cover of nurse manpower are shown in table 2. At least half the departments employ three or fewer nurses. Sixty one per cent of nurses hold a recognised $\mathrm{OH}$ qualification and a further $15 \%$ are in $\mathrm{OH}$ training positions. Sixty nine per cent of departments have one or more nurses with a degree in $\mathrm{OH}$ or an occupational health nursing diploma (OHND). Sixty nine per cent of nurses work full time, and $96 \%$ of departments have at least one full time nurse.

There was an enormous variation in the size of the NHS population served by $\mathrm{OH}$ departments (table 3). For the purpose of these comparisons, it was assumed that a restricted provision equated to half the workload of a full service. The smallest department served 450 employees, and the largest had almost 15000. 
Table 3 Occupational health department's provision for employees

\begin{tabular}{lll}
\hline & $\begin{array}{l}\text { Employees/ } \\
\text { doctor session* }\end{array}$ & $\begin{array}{l}\text { Employees/ } \\
\text { WTE nurse }\end{array}$ \\
\hline $\begin{array}{l}\text { Mean } \\
\text { Minimum }\end{array}$ & 1467 & 1838 \\
$\begin{array}{l}\text { Percentile: } \\
10\end{array}$ & 43 & 436 \\
20 & 370 & 757 \\
30 & 617 & 974 \\
40 & 735 & 1069 \\
Median & 868 & 1240 \\
Percentile: & 1040 & 1441 \\
60 & 1196 & 1617 \\
70 & 1503 & 1795 \\
80 & 2021 & 2269 \\
90 & 2534 & 3048 \\
Maximum & 8198 & 5806 \\
\hline
\end{tabular}

${ }^{\star}$ Session is taken to be one half day.

The average was just under 3700 employees, with the median at about 3200 . When the number of sessions a week of doctor time was considered, extremely wide variation was again found. The average number of potential clients per doctor session was 1467 (median 1040, range 43-8198 employees).

Considerable variation in provision of nursing time was found, but not so large as with doctors. The average was 1838 clients per nurse (median 1441, range 436-5806 employees). The correlation between the measure of doctor and nurse input was poor (Spearman's $\rho=0.16$ ) giving no indication that inadequate doctor cover is supplemented by additional nurse cover.

\section{Discussion}

In 1994 the NHS issued guidance that all health service staff should have access to a specialist $\mathrm{OH}$ service ${ }^{6}$. This study was undertaken as part of the NHSE review of provision in 1998. Previously, there was little information about the availability of $\mathrm{OH}$ services for the NHS workforce. The response rate for this study was high (89\%). However, we have looked at the 26 non-responding NHS trusts. They showed no specific characteristics in terms of size, geographical setting, or type of activity. We do not, therefore, think that there is any significant non-responder bias.

The high response allows a confident assessment of the number of NHS employees. Scaling the results suggests an estimated NHS employee workforce in England and Wales of 1.05 million. This does not include about $30000 \mathrm{GPs}$, their associated staff (estimated at 90 000), 20000 general dental practitioners (GDPs), an unknown proportion of whom provide NHS services, and their associated staff (estimated at 60000 ). This excluded group could total 200000 people. Definitive manpower data are not available. This study would estimate a total workforce active in the NHS in England and Wales of 1.3 million people, for whom $\mathrm{OH}$ services need to be provided.

In our study, only $0.4 \%$ of NHS employers reported that they did not provide any service for their employees, suggesting wide recognition of the need for $\mathrm{OH}$ services. Furthermore, only $4 \%$ of employers contracted with the pri- vate sector for their service provision. Although there are no data about why such choices were made, and the reasons could be financial, convenience, or quality, it is clear that provision of service from within the NHS is the preferred option.

Our study indicates that only $7 \%$ of health authorities provide a formal $\mathrm{OH}$ arrangement for their GPs; there were no instances of the $\mathrm{OH}$ services being available for staff employed by GPs. We found no examples of a service being provided to GDPs. This confirms anecdotal evidence of the lack of provision of a consistent service for GPs and GDPs.

Although all $\mathrm{OH}$ departments have the services of a doctor, only $38 \%$ employ a full time doctor and almost two thirds employ a doctor for half time or less. Forty four per cent of $\mathrm{OH}$ departments employ a consultant, but in only $40 \%$ of departments does this doctor hold a specialist $\mathrm{OH}$ qualification. From manpower data for the NHS workforce serviced by these departments we would estimate that only $27 \%$ of the total workforce receive specialist medical $\mathrm{OH}$ services. These findings are despite a $\mathrm{DoH}$ report in 1995 that identified that those people responsible for managing an $\mathrm{OH}$ service for NHS staff should have appropriate specialist qualifications. ${ }^{3}$ The difference between these two figures may be explained by the position which existed before 1996 when doctors appointed to consultant posts were not required to hold a specialist qualification. Alternatively, it may represent overreporting of the holding of a consultant appointment. Although we used a strict definition for the term consultant (substantive or honorary post conferred by a properly constituted advisory appointments committee), the term is widely used in occupational health outside the NHS. The holding of a specific qualification is less susceptible to overreporting and likely to represent a better measure of the proportion of specialist occupational physicians. This study shows that although 362 doctors are employed in NHS $\mathrm{OH}$ departments, this equates to 117 whole time equivalents of medical time for the care of an estimated 723000 potential patients.

For the first time, we provide an evidence based estimate of the total medical and nursing resources for $\mathrm{OH}$ services in the NHS. Although the median number of NHS staff per doctor session is about 1040, this disguises a range of 43-8198 staff per doctor session - that is, a 200 -fold variation. This must cause a huge variation in the availability of medical input to $\mathrm{OH}$ care and further emphasises the inequalities in provision of services among NHS staff. An unpublished report on $\mathrm{OH}$ services in Trent Region showed a lack of provision for staff employed by GPs and considerable variations in the levels of medical support to $\mathrm{OH}$ services. ${ }^{8}$ It also noted that many of the issues raised were likely to be generic to the NHS rather than peculiar to Trent. Our study confirms this conclusion.

Our study shows that the NHS has not yet met its 1994 self declared target of access to specialist $\mathrm{OH}$ services for all staff. Occupational health services are largely confined to 
hospitals where there is wide variation in availability of consultant led services, the number and qualifications of doctors and nurses, and potential workload. Correcting these problems will require a substantial increase in recruitment and training of staff. However, in the short term, alternative and innovative strategies could include area rather than trust based services and wider supervisory and training responsibilities of $\mathrm{OH}$ staff.

We thank all the $\mathrm{OH}$ departments who provided the information for this study. The views expressed are those of the authors. They do not necessarily reflect those of the individual NHS organisations, or of the NHSE and/or Department of Health. The study was supported by a grant from the NHSE.
1 Weale A. Rationing health care. BMF 1998;316:410. 2 Cockroft A, Williams S. Staff in the NHS. BMF 1998;316: 381.

3 Department of Health. On the state of the public health. The Annual Report of the Chief Medical Officer of the Department of Health for the year 1994. London: The Stationery Office, 1995.

4 Nuffield Provincial Hospitals Trust. Taking care of doctors' health. Report of a Working Party. London: The Nuffield Trust, 1996:35

5 Williams S, Michie S, Pattani SA. Improving the health of the NHS workforce. London: The Nuffield Trust, 1998:60.

6 NHS Executive. Health Service Guideline: occupational health services for NHS staff. London: Department of Health, 1994:51.

7 Binley's Directory of NHS Management. Vol 5, No 2. Corringham, Essex: Beechwood House, 1997.

8 Magowan R. Provision of Occupational Health Services for NHS staff in Trent. A Report to the Regional Executive Board of the Trent Regional Office of the NHS Executive. Nottingham: 1996:26. (Unpublished.)

\section{Vancouver style}

All manuscripts submitted to Occup Environ Med should conform to the uniform requirements for manuscripts submitted to biomedical journals (known as the Vancouver style.)

Occup Environ Med, together with many other international biomedical journals, has agreed to accept articles prepared in accordance with the Vancouver style. The style (described in full in the $\mathcal{F} A M A[1]$ ) is intended to standardise requirements for authors, and is the same as in this issue.

References should be numbered consecutively in the order in which they are first mentioned in the text by Arabic numerals on the line in square brackets on each occasion the reference is cited (Manson[1] confirmed other reports[2][3][4][5]). In future references to papers submitted to Occup Environ Med should include: the names of all authors if there are three or less or, if there are more, the first three followed by et al; the title of journal articles or book chapters; the titles of journals abbreviated according to the style of Index Medicus; and the first and final page numbers of the article or chapter. Titles not in Index Medicus should be given in full.

Examples of common forms of references are:

1 International Committee of Medical Journal Editors. Uniform requirements for manuscripts submitted to biomed journals. $¥ A M A$ 1993;269:2282-6.

2 Soter NA, Wasserman SI, Austen KF. Cold urticaria: Soter NA, Wasserman SI, Austen KF. Cold urticaria:
release into the circulation of histmaine and eosinophil release into the circulation of histmaine and eosinophil chemotactic factor of anaphylax

3 Weinstein L, Swartz MN. Pathogenic properties of invading micro-organisms. In: Sodeman WA Jr, Sodeman WA, eds. Pathologic physiology, mechanisms of disease. Philadelphia: W B Saunders, 1974:457-72. 